\title{
ChemComm
}

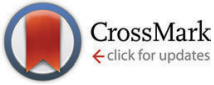

Cite this: Chem. Commun., 2015, 51, 1222

Received 20th November 2014 Accepted 28th November 2014

DOI: $10.1039 / \mathrm{c} 4 \mathrm{cc} 09271 \mathrm{f}$

\section{An $\operatorname{Ir}^{\mathrm{IV}}$-containing polyoxometalate $\dagger$}

\author{
Sergey A. Adonin, $\ddagger^{\mathrm{ab}}$ Natalya V. Izarova, $\neq^{\mathrm{c}}$ Claire Besson, ${ }^{\mathrm{cd}}$ Pavel A. Abramov, ${ }^{\mathrm{ab}}$ \\ Beatrix Santiago-Schübel, ${ }^{\text {e }}$ Paul Kögerler, ${ }^{\star}{ }^{\star c d}$ Vladimir P. Fedin ${ }^{\text {ab }}$ and \\ Maxim N. Sokolov ${ }^{\star a b}$
}

www.rsc.org/chemcomm

$\left[\mathrm{HIr}{ }^{\mathrm{IV}} \mathrm{W}_{6} \mathrm{O}_{24}\right]^{7-}$, representing the first Ir-containing AndersonEvans-type polyanion and the first structurally characterized $\mathrm{Ir}^{\mathrm{IV}}$-based polyoxometalate, has been isolated as its hydrated sodium salt and characterized by single-crystal X-ray diffraction, mass spectrometry, and IR, UV-Vis and EPR spectroscopy. Cyclic voltammetry indicates that the $\mathrm{Ir}^{\mathrm{IV}}$ ions in $\left[\mathrm{HIrW}_{6} \mathrm{O}_{24}\right]^{7-}$ can undergo reversible one-electron reduction and oxidation, resulting in $I r^{\prime \prime \prime}$ and Ir $^{\mathrm{V}}$ derivatives.

The chemistry of polyoxometalates (POMs) incorporating noble metals represents a rapidly developing area, the interest in which is driven by various fundamental and applied aspects. ${ }^{1}$ Members of this class demonstrate a range of promising properties, in particular, catalytic activity in water splitting ${ }^{2,3}$ and oxidation of various organic substrates. ${ }^{4}$ We stress, though, that the number of publications on POM complexes of Ru and Pd by far exceeds those dedicated to all remaining noble metals $(\mathrm{Pt}, \mathrm{Au}, \mathrm{Ir}$, Os and $\mathrm{Rh})$ taken together. In particular, the chemistry of Ir-containing POMs for a long time has been limited to various POM-supported $\mathrm{Ir}^{\mathrm{I}}$ - and $\mathrm{Ir}^{\mathrm{III}}$-organometallic complexes (e.g. $\left[\operatorname{Ir}^{\mathrm{I}}(1,5-\mathrm{COD})\right]^{+},\left[\operatorname{Ir}^{\mathrm{III}}\left(\mathrm{Cp}^{*}\right)\right]^{2+}$ etc. $\left.)\right)^{5}$ some of which, e.g. $\left[(1,5-\mathrm{COD}) \mathrm{Ir}^{\mathrm{I}} \mathrm{Nb}_{3} \mathrm{P}_{2} \mathrm{~W}_{15} \mathrm{O}_{62}\right]^{8-}$, are pre-catalysts for cycloalkene oxygenation with $\mathrm{O}_{2} \cdot{ }^{5 b-d}$ Recently a number of Keggin and WellsDawson type POMs with covalently grafted heteroleptic cyclometalated Ir III-complexes exhibiting effective charge separation

\footnotetext{
${ }^{a}$ Nikolaev Institute of Inorganic Chemistry SB RAS, 630090 Novosibirsk, Russia.

E-mail: caesar@niic.nsc.ru; Fax: +7 383-330-94-89; Tel: +7 383-316-58-45

${ }^{b}$ Novosibirsk State University, 630090 Novosibirsk, Russia

${ }^{c}$ Peter Grünberg Institute - PGI 6, Forschungszentrum Jülich, D-52425 Jülich, Germany.E-mail: paul.koegerler@ac.rwth-aachen.de

${ }^{d}$ Institute of Inorganic Chemistry, RWTH Aachen University, D-52074 Aachen, Germany

${ }^{e}$ Central Institute for Engineering, Electronics and Analytics - ZEA 3,

Forschungszentrum Jülich, D-52425 Jülich, Germany

$\dagger$ Electronic supplementary information (ESI) available: Crystallographic data in CIF format; details on synthesis, crystallographic and electrochemical studies; crystal packing in Na-IrW, bond valence sum values; mass spectrometry; IR and UV-Vis spectra. See DOI: 10.1039/c4cc09271f

\# These authors contributed equally.
}

between the $\operatorname{Ir}^{\mathrm{II}}$-based chromophore and the POM unit were reported. ${ }^{6}$ The first reliably characterized iridium-containing POM incorporating no organometallic fragments, $\left[\left(\mathrm{Ir}^{\mathrm{III}} \mathrm{Cl}_{4}\right)\left(\mathrm{P}_{2} \mathrm{~W}_{20} \mathrm{O}_{72}\right)\right]^{15-}$, was reported as late as in 2009 by Hill's group and identified as a water oxidation catalyst. ${ }^{3}$ Two years later, the synthesis, characterization and reactivity of Keggin-type complexes $\left[\mathrm{PW}_{11} \mathrm{O}_{39} \mathrm{Ir}^{\mathrm{III}} \mathrm{L}\right]^{n-}\left(n=4\right.$ or $\left.5 ; \mathrm{L}=\mathrm{H}_{2} \mathrm{O}, \mathrm{OH}, \mathrm{CH}_{3}, \mathrm{Cl}, \mathrm{SCN}\right)$ were reported. ${ }^{7}$ Yet, POMs incorporating Ir $^{\mathrm{IV}}$ centers, which are of interest as promoters or intermediates in oxidation reactions, remain unknown. For this oxidation state, we expect Ir-containing polyoxotungstates or molybdates to adopt the Anderson-Evans structure, in analogy to known $\mathrm{Rh}^{\mathrm{III}},{ }_{8} \mathrm{Pt}^{\mathrm{IV}}, 9,10$ and even $\mathrm{Pd}^{\mathrm{IV}}$ derivatives. ${ }^{11}$

We report the preparation of $\left[\mathrm{HII}^{\mathrm{IV}} \mathrm{W}_{6}{ }^{\mathrm{VI}} \mathrm{O}_{24}\right]^{7-}$ (IrW), the first polyoxometalate incorporating $\mathrm{Ir}^{\mathrm{IV}}$, and its characterization by single-crystal X-ray analysis, mass spectrometry, IR, UV-Vis and EPR spectroscopy, as well as cyclic voltammetry.

IrW assembles in condensation reactions of in situ-formed Ir $^{\mathrm{IV}}$ hydroxo complexes with tungstate ions in aqueous acetate media. In a first step, $\mathrm{IrCl}_{3} \cdot 3 \mathrm{H}_{2} \mathrm{O}$ was dissolved in a $\mathrm{CH}_{3} \mathrm{COONa}$ solution and the $\mathrm{pH}$ of the reaction mixture was adjusted to 12 with $6 \mathrm{M} \mathrm{NaOH}$. Heating of the solution led to a gradual color change from brown-green to blue and then to purple. Previous studies on alkaline solutions of hexachloroiridate(III) have shown that the processes in such reaction systems include substitution of $\mathrm{Cl}^{-}$ligands in the inner coordination sphere of the $\mathrm{Ir}^{\mathrm{III}}$ ions by $\mathrm{OH}^{-}$groups and the subsequent oxidation of thus formed hydroxo-oxo complexes of Ir $^{\mathrm{III}}$ in air. ${ }^{12}$ During the reaction, the color change of the $\operatorname{Ir}^{\mathrm{IV}}$-containing solutions from blue to purple is apparently caused by (not well-defined) oligomerization processes. Another hypothesis postulates transformation of the blue superoxo dimeric $\left[(\mathrm{OH})_{5} \operatorname{Ir}^{\mathrm{IV}}\left(\mu-\mathrm{O}_{2}{ }^{-}\right) \mathrm{Ir}^{\mathrm{IV}}(\mathrm{OH})_{5}\right]^{3-}$ species into the purple $\left[(\mathrm{OH})_{4} \operatorname{Ir}^{\mathrm{IV}}\left(\mu-\mathrm{O}_{2}{ }^{2-}\right)(\mu-\mathrm{OH}) \mathrm{Ir}^{\mathrm{IV}}(\mathrm{OH})_{5}\right]^{3-}$ complex, based on UV-Vis and EPR studies of $3 \mathrm{M} \mathrm{KOH}$ solutions of $\left[\mathrm{IrCl}_{6}\right]^{3-} \cdot{ }^{12 f} \mathrm{Next}$, the solution of the in situ-formed $\operatorname{Ir}^{\mathrm{IV}}$ hydroxo complexes was added dropwise to a solution containing the lacunary $\left[\mathrm{B}-\alpha-\mathrm{PW}_{9} \mathrm{O}_{34}\right]^{9-}$ polyanion under careful control of $\mathrm{pH}$ kept strictly between 6 and 7 by addition of diluted nitric acid. 
$\left[\mathrm{B}-\alpha-\mathrm{PW}_{9} \mathrm{O}_{34}\right]^{9-}$ is unstable in solution and acts as a source of free $\mathrm{WO}_{4}{ }^{2-}$ species, which effectively assemble and condense around $\mathrm{Ir}^{\mathrm{IV}}$, resulting in IrW. This is conceptually similar to the controlled formation of $\mathrm{Mn}^{\mathrm{III}}$ species by slow hydrolysis of $\left[\mathrm{Mn}_{12}\left(\mathrm{CH}_{3} \mathrm{COO}\right)_{16}\left(\mathrm{H}_{2} \mathrm{O}\right)_{4} \mathrm{O}_{12}\right]$ in the synthesis of Mn-substituted polyoxotungstates. ${ }^{13}$ It should be noted that both monoprotonated and non-protonated forms of $\left[\mathrm{Ir}^{\mathrm{IV}} \mathrm{W}^{\mathrm{VI}} \mathrm{O}_{24}\right]^{8-}\left(\mathbf{I r W}^{\prime}\right)$ can be isolated as the hydrated sodium salts $\mathrm{Na}_{6} \mathrm{H}\left[\mathrm{HIr}^{\mathrm{IV}} \mathrm{W}^{\mathrm{VI}} \mathrm{O}_{24}\right] \cdot 26 \mathrm{H}_{2} \mathrm{O}(\mathbf{N a}-\mathbf{I r W})$ and $\mathrm{Na}_{8}\left[\mathrm{Ir}^{\mathrm{IV}} \mathrm{W}^{\mathrm{VI}} \mathrm{O}_{24}\right] \cdot 26 \mathrm{H}_{2} \mathrm{O}\left(\mathrm{Na}_{8}-\mathrm{IrW}^{\prime}\right)$, respectively. The exact protonation state depends on the final $\mathrm{pH}$ of the reaction mixture.

Thus, pure Na-IrW crystals form when the final $\mathrm{pH}$ of the reaction mixture before crystallization is set within the range of 6.1-6.5. At higher final $\mathrm{pH}(7.0-7.5)$ crystals of $\mathbf{N a}_{\mathbf{8}}-\mathbf{I r W}$ form as a byproduct to Na-IrW. No crystals could be isolated at $\mathrm{pH}>$ 7.6 where one could expect formation of pure $\mathbf{N a}_{\mathbf{8}}-\mathbf{I r W} \mathbf{W}^{\prime}$. We herein focus on the monoprotonated species and provide structural data for $\mathbf{N a}_{\mathbf{8}}-\mathrm{IrW}^{\prime}$ in the ESI. $\dagger$

Our attempts to rationalize the synthetic procedure by reacting $\mathrm{Ir}^{\mathrm{IV}}$ solutions directly with $\mathrm{Na}_{2} \mathrm{WO}_{4}$ at various ratios were not successful and resulted in formation of the paratungstate salt $\mathrm{Na}_{10}\left[\mathrm{H}_{2} \mathrm{~W}_{12} \mathrm{O}_{42}\right] \cdot 25 \mathrm{H}_{2} \mathrm{O}$ as the main product, as established via single-crystal X-ray measurements and IR spectroscopy. We conjecture that an initial excess of $\operatorname{Ir}^{\mathrm{IV}}$ ions coupled with the gradual release of $\mathrm{WO}_{4}{ }^{2-}$ species into the reaction medium are key to successful preparation of IrW. Alternatively, IrW can be prepared by prolonged heating of $\mathrm{K}_{2}\left[\mathrm{IrF}_{6}\right]$ with $\mathrm{Na}_{2} \mathrm{WO}_{4}$ in water at neutral $\mathrm{pH}$, however, this reaction is not very well reproducible and the IrW salts could be isolated only in a low yield ( $\leq 10 \%)$.

The compound $\mathrm{Na}_{6} \mathrm{H}\left[\mathrm{HIr}^{\mathrm{IV}} \mathrm{W}_{6}{ }^{\mathrm{VI}} \mathrm{O}_{24}\right] \cdot 26 \mathrm{H}_{2} \mathrm{O}$ (Na-IrW) crystallizes in the triclinic space group $P \overline{\mathbf{1}}$. The IrW polyanions display an Anderson-Evans-type ring structure comprising a central $\mathrm{Ir}^{\mathrm{IV}} \mathrm{O}_{6}$ octahedron surrounded by six distorted edge-sharing $\mathrm{W}^{\mathrm{VI}} \mathrm{O}_{6}$ octahedra (Fig. 1). All metal centers in the $\mathrm{IrW}_{6}$ core define a single plane and form a virtually regular Ir-centered $\mathrm{W}_{6}$

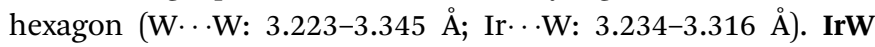
has idealized $D_{3 \mathrm{~d}}$ symmetry and thus belongs to the A-type family of polyanions with Anderson-Evans structure which is typical for $\left[\mathrm{M}^{\prime} \mathrm{W}_{6} \mathrm{O}_{24}\right]^{n-}$ heteropolyoxotungstates. In contrast, some of the polyoxomolybdates $\left[\mathrm{M}^{\prime} \mathrm{Mo}_{6} \mathrm{O}_{24}\right]^{n-}$ may also adopt a bent conformation with $C_{2 \mathrm{v}}$ symmetry (usually referred as a B-type Anderson-Evans structure), which was e.g. found in

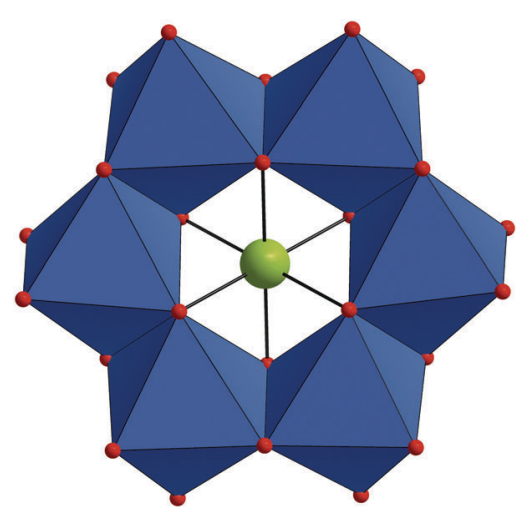

Fig. 1 Structure of IrW. Color code: $\mathrm{WO}_{6}$, blue octahedra; Ir, green; O, red.
$\left[\mathrm{H}_{4} \mathrm{PtMo}_{6} \mathrm{O}_{24}\right]^{4-},{ }^{9 a, c-e}\left[\mathrm{H}_{2} \mathrm{SbMo}_{6} \mathrm{O}_{24}\right]^{5-}$ (ref. 14) and heptamolybdate $\left[\mathrm{Mo}_{7} \mathrm{O}_{24}\right]^{6-}$ ions. $^{15}$

There are three types of oxygen atoms in IrW: $\mu_{3}-\mathrm{O}$ linking $\mathrm{Ir}^{\mathrm{IV}}$ and two $\mathrm{W}^{\mathrm{VI}}$ centers (Ir-O: 1.994(5)-2.022(5) $\AA$; W-O: 2.142(5)-2.293(5) $\mathrm{A}), \mu_{2}-\mathrm{O}$ bridging two $\mathrm{W}^{\mathrm{VI}}$ ions (W-O: 1.923(5)-1.987(5) $\AA$ ) and terminal $\mathrm{O}$ atoms $(\mathrm{W}=\mathrm{O}: 1.735(5)-$ $1.747(5) \AA)$. The average Ir-O bond length in IrW of $2.004 \AA$ is comparable with that of $2.013 \AA$ observed in the only structurally characterized $\mathrm{Ir}^{\mathrm{III}}$-containing all-inorganic polyoxotungstate $\left[\left(\mathrm{Ir}^{\mathrm{III}} \mathrm{Cl}_{4}\right) \mathrm{P}_{2} \mathrm{~W}_{20} \mathrm{O}_{72}\right]^{15-3}$, and with that in $\mathrm{Ir}^{\mathrm{IV}}$ oxides, e.g. $\mathrm{CaIrO}_{3}(2.057 \AA) .{ }^{16}$ The $\mathrm{W}-\mathrm{O}$ distances in IrW are similar to the $\mathrm{W}-\mathrm{O}$ bond lengths in other $\left[\mathrm{XW}_{6} \mathrm{O}_{24}\right]^{n-}$ species $\left(\mathrm{X}=\mathrm{Pt}^{\mathrm{IV}}, \mathrm{Te}^{\mathrm{IV}}\right.$, $\left.\mathrm{Mn}^{\mathrm{IV}}, n=8 ; \mathrm{X}=\mathrm{Sb}^{\mathrm{V}}, n=7\right) .{ }^{10,17}$ Bond valence sum calculations (Table S2, ESI $\dagger$ ) suggest a disorder of a proton over two inversion center related $\mu_{3}-\mathrm{O}$ atoms (O123) in IrW. The second proton, which should be present in the structure of Na-IrW from the charge balance considerations (only six $\mathrm{Na}^{+}$countercations were found both in X-ray diffraction and elemental analyses of Na-IrW), is either highly disordered over the terminal oxygens of the IrW polyanions (BVS 1.60-1.67) or, more likely, is associated with an oxygen of a co-crystallized water molecule, i.e. as a $\mathrm{H}_{3} \mathrm{O}^{+}$cation. In the crystal lattice of Na-IrW the $\mathrm{Na}^{+}$countercations and the crystal water molecules assemble in the parallel infinite zig-zag $\left\{\mathrm{Na}_{6}\left(\mu_{2}-\mathrm{H}_{2} \mathrm{O}\right)_{10}\left(\mathrm{H}_{2} \mathrm{O}\right)^{t}{ }_{14}\right\}_{n}{ }^{6 n+}$ chains. The IrW polyanions are packed between the chains (see $\mathrm{ESI} \dagger$ for details) and form an extended net of hydrogen bonds with the $\mathrm{H}$ atoms of the $\mathrm{H}_{2} \mathrm{O}$ molecules (Fig. $\mathrm{S} 1$ and Table S4, ESI $\dagger$ ).

The oxidation state of the iridium center $\left(\operatorname{Ir}^{\mathrm{IV}}, 5 \mathrm{~d}^{5}, S=1 / 2\right)$ was further confirmed by the characteristic EPR signal around $g=2$ (Fig. 2). The complexity of the powder spectrum indicates the strong contribution of quadrupole as well as hyperfine coupling ( $I=3 / 2$ for ${ }^{191} \operatorname{Ir}$ [natural abundance $37 \%$ ] and ${ }^{193} \mathrm{Ir}$ [63\%]), similar to what has been observed for iridium(Iv) impurities displaying a tetragonally distorted octahedral environment in $\mathrm{MgO}$ and $\mathrm{CaO}$ matrices. ${ }^{18}$ Unfortunately, low distortion of the iridium coordination sphere in IrW leads to a small split between $g$ values, and the resulting overlap of the various components in our powder X-band spectrum precludes direct determination of the hyperfine and quadrupole coupling constants, while the large number of variables renders an exhaustive search of the parameter space impracticable.

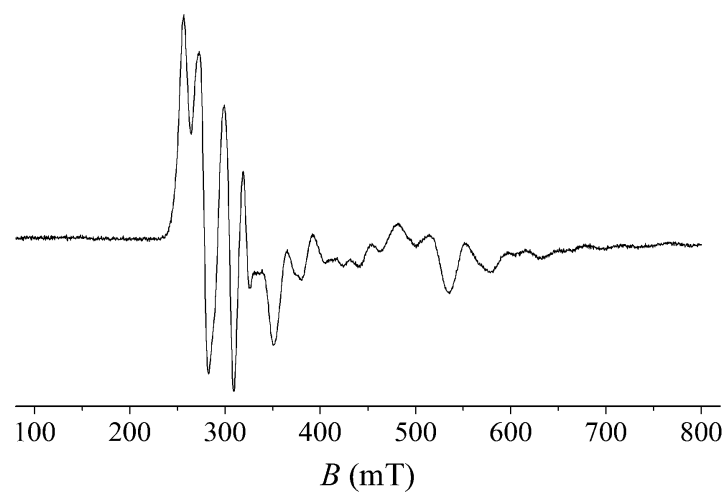

Fig. 2 Powder X-band EPR spectrum of $\mathrm{Na}-\mathrm{IrW}$ at $110 \mathrm{~K}$. 


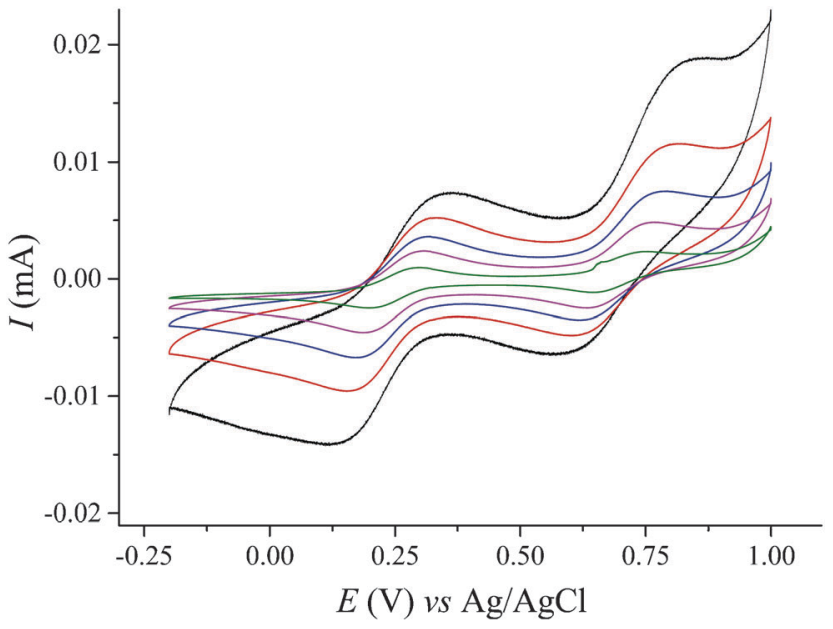

Fig. $3 \mathrm{CV}$ of $1.3 \mathrm{mM} \mathrm{Na}$-IrW solution in $2 \mathrm{M} \mathrm{NaOAc}$ medium (pH 6.1) at different scan rates: $10 \mathrm{mV} \mathrm{s}^{-1}$ (green), $25 \mathrm{mV} \mathrm{s}^{-1}$ (pink), $50 \mathrm{mV} \mathrm{s}^{-1}$ (blue), $100 \mathrm{mV} \mathrm{s}^{-1}$ (red), $250 \mathrm{mV} \mathrm{s}^{-1}$ (black) vs. $\mathrm{Ag} / \mathrm{AgCl}$.

The ESI mass spectrum obtained by ionization of Na-IrW solution in $\mathrm{H}_{2} \mathrm{O} / \mathrm{MeOH}$ is very complex and exhibits signals which could be assigned for the doubly negatively charged ion pairs $\left\{\mathrm{Na}_{4} \mathrm{H}_{2}\left[\mathrm{Ir}^{\mathrm{IV}} \mathrm{W}_{6}{ }^{\mathrm{VI}} \mathrm{O}_{24}\right]\right\}^{2-}$ and $\left\{\mathrm{Na}_{3} \mathrm{H}_{3}\left[\operatorname{Ir}^{\mathrm{IV}} \mathrm{W}_{6}{ }^{\mathrm{VI}} \mathrm{O}_{24}\right]\right\}^{2-}$ as well as sets of signals corresponding to various decomposition products, e.g. $\left[\mathrm{HWO}_{4}\right]^{-},\left[\mathrm{HW}_{2} \mathrm{O}_{7}\right]^{-}, \mathrm{Na}_{x} \mathrm{H}_{5-x}\left[\mathrm{IrW}_{5} \mathrm{O}_{20}\right]^{2-}$ etc. (see $\mathrm{ESI} \dagger$ ). While it confirms the existence of the intact polyanions in aqueous solutions the obtained data do not answer the question if the partial decomposition starts to occur already in the solution or only happens during the ionization process. The stability of the polyanions in aqueous solution as well as aqueous acetate media with different $\mathrm{pH}$ has been further checked by UV-vis spectroscopy (see ESI $\dagger$ for details). Electrochemistry studies of IrW in aqueous $\mathrm{CH}_{3} \mathrm{COONa}$ solution at $\mathrm{pH} 6.1$ (see ESI $\dagger$ ) produce typical voltammograms (Fig. 3) that show two quasi-reversible redox couples with the corresponding peak potentials $E_{1 / 2}$ located at $0.245 \mathrm{~V}(\Delta E=0.190 \mathrm{~V}$ at $\left.100 \mathrm{mV} \mathrm{s}^{-1}\right)$ and $0.700 \mathrm{~V}(\Delta E=0.200 \mathrm{~V}) v s$. $\mathrm{Ag} / \mathrm{AgCl}$ reference electrode ( $0.441 \mathrm{~V}$ and $0.896 \mathrm{~V}$ vs. SHE, respectively). These waves are attributed to the $\mathrm{Ir}^{\mathrm{III}} / \mathrm{Ir}^{\mathrm{IV}}$ and $\mathrm{Ir}^{\mathrm{IV}} / \mathrm{Ir}^{\mathrm{V}}$ redox transformations within the polyanion $\left[\mathrm{HIrW}_{6} \mathrm{O}_{24}\right]^{n-}$. The observed $\mathrm{Ir}^{\mathrm{III}} / \mathrm{Ir}^{\mathrm{IV}}$ potential value is similar to $0.18 \mathrm{~V}$ found for the $\mathrm{Ir}^{\mathrm{III}} / \mathrm{Ir}^{\mathrm{IV}}$ transition in $\left[\mathrm{PW}_{11} \mathrm{O}_{39} \mathrm{Ir}^{\mathrm{III}}\left(\mathrm{H}_{2} \mathrm{O}\right)\right]^{4-}$, and the $\mathrm{Ir}^{\mathrm{IV}} / \mathrm{Ir}^{\mathrm{V}}$ couple is close to the potential of irreversible oxidation of the Ir centers in the same POM 0.75 V (vs. Ag/AgCl) ${ }^{7 a}$ The significant shift to lower potentials as compared with the $\mathrm{Ir}^{\mathrm{II}} / \mathrm{Ir}^{\mathrm{IV}}$ couple observed in the hexachloroiridates $\left(0.669 \mathrm{~V} v s\right.$. $\left.\mathrm{Ag} / \mathrm{AgCl}^{19}\right)$ is consistent with the stabilization of higher oxidation states of transition metals generally observed in the oxygen environment provided by polyoxometalates. The relative broadness of the waves could be due to uncompensated solution resistance but this can be ruled out since no change was observed upon increase of the electrolyte concentration. A deviation from reversibility is to be also excluded by the fact that the peak currents for the both processes remain proportional to the square root of the scan rate (Fig. S11, ESI $\dagger$ ), indicating diffusion-controlled electrode reactions for scan rates up to $1 \mathrm{~V} \mathrm{~s}^{-1} \cdot{ }^{20}$ The diffusion coefficient $D=2.62 \times 10^{-6} \mathrm{~cm}^{2} \mathrm{~s}^{-1}$ calculated for $\left[\mathrm{HIr}^{\mathrm{IV}} \mathrm{W}_{6} \mathrm{O}_{24}\right]^{7-}$ according to Randles-Sevcik equation ${ }^{21}$ compares well to the values reported for other polyoxotungstates. ${ }^{22}$ The broadness of the redox waves reflects the co-existence of multiple protonation states at $\mathrm{pH}=6.1$. This is supported by significant narrowing of the waves when the $\mathrm{pH}$ decreases to 4.3 (Fig. S12, ESI $\dagger$ ), as well as by isolation of the non-protonated form, $\mathbf{I r W}^{\prime}$, at $\mathrm{pH}>6.5$ (vide supra). Detailed studies of the protonation phenomena are underway. The redox couples associated with reduction of tungsten(vi) centers in IrW are not accessible, which is typical for $\mathrm{W}^{\mathrm{VI}}$ centers in POMs possessing two terminal cis-oxo ligands. ${ }^{23}$

In summary, the identified synthetic path leading to new $\mathrm{Ir}^{\mathrm{IV}}$-based polyoxotungstate with Anderson-Evans structure, $\left[\mathrm{HIr}^{\mathrm{IV}} \mathrm{W}_{6} \mathrm{O}_{24}\right]^{7-}$, comprises the use of in situ-formed $\mathrm{Ir}^{\mathrm{IV}}$ oxohydroxo complexes and tungstate ions gradually released in solution. The IrW polyanion is the first example of a structurally characterized $\operatorname{Ir}^{\mathrm{IV}}$-containing POM as well as the first Ir-based POM with Anderson-Evans structure. The $\operatorname{Ir}^{\mathrm{IV}}$ oxidation state in IrW has been directly confirmed by EPR spectroscopy and the cyclic voltammetry measurements showed the possibility of reversible oxidation and reduction of the $\operatorname{Ir}^{\mathrm{IV}}$ ions in IrW resulting in $\operatorname{Ir}^{\mathrm{V}}$ and $\mathrm{Ir}^{\mathrm{III}}$ species. Our results suggest existence of a rich $\operatorname{Ir}^{\mathrm{IV}}$-POM and possibly even $\operatorname{Ir}^{\mathrm{V}}$-POM chemistry that we are planning to elucidate.

PK appreciates EU financial support (ERC Starting Grant MOLSPINTRON, no. 308051). The work has been supported by RFBR grant No. 13-03-00012 (to MNS). Support by President fellowship to SAA is gratefully acknowledged.

\section{Notes and references}

1 (a) P. Putaj and F. Lefebvre, Coord. Chem. Rev., 2011, 255, 1642; (b) N. V. Izarova, M. T. Pope and U. Kortz, Angew. Chem., Int. Ed., 2012, 51, 9492.

2 See for example: (a) M. N. Sokolov, S. A. Adonin, P. A. Abramov, D. A. Mainichev, N. F. Zakharchuk and V. P. Fedin, Chem. Commun., 2012, 48, 6666; (b) H. J. Lv, Y. V. Geletii, C. C. Zhao, J. W. Vickers, G. B. Zhu, Z. Luo, J. Song, T. Q. Lian, D. G. Musaev and C. L. Hill, Chem. Soc. Rev., 2012, 41, 7572; (c) A. Sartorel, M. Bonchio, S. Campagna and F. Scandola, Chem. Soc. Rev., 2013, 42, 2262 and references therein.

3 R. Cao, H. Ma, Y. V. Geletii, K. I. Hardcastle and C. L. Hill, Inorg. Chem., 2009, 48, 5596.

4 See for example: (a) C. N. Kato, A. Shinohara, N. Moriya and K. No-miya, Catal. Commun., 2006, 7, 413; (b) L. D. Dingwall, C. M. Corcoran, A. F. Lee, L. Olivi, L. M. Lynam and K. Wilson, Chem. Commun., 2008, 53; (c) R. Neumann and D. Barats, Adv. Synth. Catal., 2010, 352, 293; (d) M. N. Sokolov, S. A. Adonin, E. V. Peresypkina, P. A. Abramov, A. I. Smolentsev, D. I. Potemkin, P. V. Snytnikov and V. P. Fedin, Inorg. Chim. Acta, 2013, 394, 656 and references therein.

5 (a) See ref. $1 a$ the references therein and; $(b)$ N. Mizuno, D. K. Lyon and R. G. Finke, J. Catal., 1991, 128, 84; (c) N. Mizuno, H. Weiner and R. G. Finke, J. Mol. Catal. A: Chem., 1996, 114, 15; (d) H. Weiner, A. Trovarelli and R. G. Finke, J. Mol. Catal. A: Chem., 2003, 191, 253; (e) G. Modugno, A. Monney, M. Bonchio, M. Albrecht and M. Carraro, Eur. J. Inorg. Chem., 2014, 2356.

6 (a) B. Matt, J. Moussa, L. M. Chamoreau, C. Afonso, A. Proust, H. Amouri and G. Izzet, Organometallics, 2012, 31, 35; (b) B. Matt, X. Xiang, A. L. Kaledin, N. N. Han, J. Moussa, H. Amouri, S. Alves, C. L. Hill, T. Q. Lian, D. G. Musaev, G. Izzet and A. Proust, Chem. Sci., 2013, 4, 1737; (c) B. Matt, J. Fize, J. Moussa, H. Amouri, A. Pereira, V. Artero, G. Izzet and A. Proust, Energy Environ. Sci., 2013, 6, 1504.

7 (a) M. N. Sokolov, S. A. Adonin, D. A. Mainichev, C. Vicent, N. F. Zakharchuk, A. M. Danilenko and V. P. Fedin, Chem. Commun., 
2011, 47, 7833; (b) M. N. Sokolov, S. A. Adonin, P. L. Sinkevich, C. Vicent, D. A. Mainichev and V. P. Fedin, Dalton Trans., 2012, 41, 9889; (c) M. N. Sokolov, S. A. Adonin, P. L. Sinkevich, C. Vicent, D. A. Mainichev and V. P. Fedin, Z. Anorg. Allg. Chem., 2014, 640, 122.

8 (a) G. A. Barbieri, Atti Accad. Lincei, 1914, 23, 334; (b) Y. Ozawa, Y. Hayashi and K. Isobe, Acta Crystallogr., Sect. C: Cryst. Struct. Commun., 1991, 47, 637; (c) G. Z. Kaziev, S. H. Quinones, V. K. Bel'skii, V. E. Zavodnik and I. V. Osminkina, Russ. J. Inorg. Chem., 2002, 47, 14 .

9 For $\mathrm{PtMo}_{6}$ see for example: (a) U. Lee and Y. Sasaki, Chem. Lett., 1984, 1297; (b) U. Lee, Bull. Korean Chem. Soc., 1988, 9, 256; (c) K.-M. Park and U. Lee, Chem. Lett., 1989, 1943; (d) U. Lee and Y. Sasaki, Bull. Korean Chem. Soc., 1994, 15, 37; (e) H.-C. Joo, K.-M. Park and U. Lee, Acta Crystallogr., Sect. C: Cryst. Struct. Commun., 1994, 50, 1659; $(f)$ U. Lee, H.-C. Joo and K.-M. Park, Acta Crystallogr., Sect. E: Struct. Rep. Online, 2010, 66, i25.

10 For PtW 6 see: (a) U. Lee, A. Kobayashi and Y. Sasaki, Acta Crystallogr., Sect. C: Cryst. Struct. Commun., 1983, 39, 817; (b) U. Lee, H. Ichida, A. Kobayashi and Y. Sasaki, Acta Crystallogr., Sect. C: Cryst. Struct. Commun., 1984, 40, 5; (c) U. Lee and Y. Sasaki, Taehan Hwahakhoe Chi, 1987, 31, 118; (d) R. E. Marsh and I. Bernal, Acta Crystallogr., Sect. B: Struct. Sci., 1995, 51, 300; (e) U. Lee, Acta Crystallogr., Sect. E: Struct. Rep. Online, 2002, 58, 130; $(f)$ U. Lee, S.-J. Jang, H.-C. Joo and K.-M. Park, Acta Crystallogr., Sect. E: Struct. Rep. Online, 2003, 59, i116; $(g)$ U. Lee and H.-C. Joo, Acta Crystallogr., Sect. E: Struct. Rep. Online, 2004, 60, i33; (h) U. Lee, H.-C. Joo and K.-M. Park, Acta Crystallogr., Sect. E: Struct. Rep. Online, 2004, 60, i55; (i) U. Lee and H.-C. Joo, Acta Crystallogr., Sect. E: Struct. Rep. Online, 2004, 60, i86.

11 S. Angus-Dunne, R. C. Burns, D. C. Craig and G. A. Lawrance, Z. Anorg. Allg. Chem., 2010, 636, 727.

12 (a) J. M. P. Cabral, J. Inorg. Nucl. Chem., 1964, 26, 1657; (b) J. C. Chahg and C. S. Garner, Inorg. Chem., 1965, 4, 209; (c) A. A. El-Awady, E. J. Bounsall and C. S. Garner, Inorg. Chem., 1967, 6, 79; (d) D. A. Fine, Inorg. Chem., 1969, 8, 1014; (e) S. E. Castillo-Blum,
D. T. Richens and A. G. Sykes, Inorg. Chem., 1989, 28, 954; $(f)$ D. A. Pankratov, P. N. Komozin and Y. M. Kiselev, Russ. J. Inorg. Chem., 2011, 56, 1794.

13 X. Fang, P. Kögerler, Y. Furukawa, M. Speldrich and M. Luban, Angew. Chem., Int. Ed., 2011, 50, 5212.

14 A. Ogawa, H. Yamato, U. Lee, H. Ichida, A. Kobayashi and Y. Sasaki, Acta Crystallogr., Sect. C: Cryst. Struct. Commun., 1988, 44, 1879.

15 I. Lindqvist, Acta Crystallogr., 1950, 3, 159.

16 M. Sugahara, A. Yoshiasa, A. Yoneda, T. Hashimoto, S. Sakai, M. Okube, A. Nakatsuka and O. Ohtaka, Am. Mineral., 2008, 93, 1148.

$17 \mathrm{SbW}_{6}$ : (a) U. Lee and Y. Sasaki, Bull. Korean Chem. Soc., 1987, 8, 1; (b) H. Naruke and T. Yamase, Acta Crystallogr., Sect. C: Cryst. Struct. Commun., 1992, 48, 597; (c) H. Naruke, N. Kajitani and T. Konya, J. Solid State Chem., 2011, 184, 770; $\mathrm{MnW}_{6}:(d)$ V. S. Sergienko, V. N. Molchanov, M. A. Porai Koshits and E. A. Torchenkova, Koord. Khim., 1979, 5, 936; (e) A. L. Nolan, R. C. Burns, G. A. Lawrance and D. C. Craig, Acta Crystallogr., Sect. C: Cryst. Struct. Commun., 2000, 56, 729; $(f)$ A. V. Oreshkina, G. Z. Kaziev, S. H. Quinones, A. I. Stash and P. A. Shipilova, Russ. J. Coord. Chem., 2011, 37, 845; TeW : $^{\circ}$ $(g)$ K. J. Schmidt, G. J. D. Schrobilgen and J. F. Sawyer, Acta Crystallogr., Sect. C: Cryst. Struct. Commun., 1986, 42, 1115.

18 A. Raizman and J. T. Suss, Phys. Rev. B: Condens. Matter Mater. Phys., $1980,22,1141$.

19 P. George, I. H. Hanania and D. H. Irvine, J. Chem. Soc., 1957, 3048.

20 A. M. Bond, Broadening Electrochemical Horizons, Oxford University Press, 2003.

21 A. J. Bard and L. R. Faulkner, Electrochemical Methods: Fundamentals and Applications, John Wiley \& Sons, New York, 1980.

22 See for example: (a) C. Rong and F. C. Anson, Inorg. Chem., 1994, 33, 1064; (b) G. Bernardini, A. G. Wedd, C. Zhao and A. M. Bond, Dalton Trans., 2012, 41, 9944.

23 (a) D. H. Brown and J. A. Mair, J. Chem. Soc., 1958, 2597; (b) P. Souchay and R. Contant, Bull. Soc. Chim. Fr., 1973, 3287; (c) S. C. Termes and M. T. Pope, Transition Met. Chem., 1978, 3, 103. 